Original Article

\title{
SELECTIVE MERCURIMETRIC TITRATION ASSAY OF CHLORIDE CONCENTRATION IN THE WATER OF GREEN COCONUTS USING NOVEL INDICATOR SYSTEM
}

\author{
SHIVAJI RANGNATH LABHADE* \\ Department of Chemistry, K. R. T. Arts, B. H. Commerce and A. M. Science (K. T. H. M.) College, Nashik 422002, Savitribai Phule Pune \\ University, Maharashtra, India \\ Email: srlabhade3571@rediffmail.com
}

Received: 19 Dec 2016 Revised and Accepted: 30 Jan 2017

\begin{abstract}
Objective: A selective mercurimetric titration procedure is proposed for the assay of chloride concentration in the water of green coconut using mercury (II) nitrate $\left[\left(\mathrm{Hg}\left(\mathrm{NO}_{3}\right)_{2}\right]\right.$ reagent and iron(III) nitrate $\left[\mathrm{Fe}\left(\mathrm{NO}_{3}\right)_{3}\right]$ with synthetically prepared mercury(II) thiocyanate $\left[\mathrm{Hg}(\mathrm{SCN})_{2}\right]$ indicator system.

Methods: An indicator solution was prepared by titrating $\mathrm{Hg}\left(\mathrm{NO}_{3}\right)_{2}$ against potassium thiocyanate $(\mathrm{KSCN})$ till a red color end point using Fe( $\left.\mathrm{NO}_{3}\right)_{3}$. Then a known amount of $\mathrm{Hg}\left(\mathrm{NO}_{3}\right)_{2}$ was added to indicator solution and titrated against the water of green coconut till the original red color reappeared.

Results: The concentration of chloride present in the volume of coconut water utilized in between these two end points was found to be reacting in the 2:1 stoichiometric ratio with the $\mathrm{Hg}\left(\mathrm{NO}_{3}\right)_{2}$ taken in the second step of the titration. The statistical treatment of the experimental data obtained by using standard solutions of sodium chloride $(\mathrm{NaCl})$ indicates that the procedure is precise and accurate. The phosphate, sulfate, organic compounds and inorganic minerals present in the coconut water did not interfere with the measurement of chloride by this procedure. Both the cationic mineral value (was also determined by complexometric titration) and chloride concentration in the coconut water were found to be decreased with the development of the coconuts.
\end{abstract}

Conclusion: The proposed procedure of determination of chloride concentration in the water of green coconut is simple, reliable and inexpensive. This procedure is excellent for determination of chloride in the acidic solution without precise adjustment of the $\mathrm{pH}$ for detection of the end point. Owing to the homogenous reaction condition no titration errors those are commonly encountered by co-precipitation in the argentometric assay of chloride.

Keywords: Chloride concentration, Cationic mineral value, Green coconut water, Mercurimetric titration assay, Mercury(II) nitrate, Mercury(II) thiocyanate-iron(III) nitrate

(C) 2016 The Authors. Published by Innovare Academic Sciences Pvt Ltd. This is an open access article under the CC BY license (http://creativecommons.org/licenses/by/4.0/] DOI: http://dx.doi.org/10.22159/ijpps.2017v9i3.16691

\section{INTRODUCTION}

Coconut is a tree cultivated for its multiple utilities for the human life. The fruit of immature coconut consists of a large amount of the clear liquid called as coconut water. Coconut water starts to be produced into the fruit nearly after two months. As the coconut matures, the water is replaced by coconut meat [1]. Coconut water is rich in carbohydrates, low fats and minerals such as potassium, sodium, calcium and magnesium in their chloride, sulfate, and phosphate salts; which makes coconut water as an excellent refreshing drink [2-3].

Determination of chloride concentration in different samples is the common parameter measured in all clinical and chemical laboratories. The most common titrimetric methods for determination of chloride are Mohr method [4-5], Volhard method [5], Fajans method [4-5] and turbidimetric titration [6-7]. In Mohr method phosphate, arsenate, chromate, sulfide, and oxalates are the main interfering anions for determination of chloride in neutral solution [4-5]. Therefore, for removal of the interference of these anions, in Volhard procedure initially precipitation of silver chloride is carried out in dilute nitric acid and the residual silver nitrate is estimated by titration against thiocyanate solution [5]. The coprecipitation of thiocyanate ions over silver chloride precipitate is the major problem associated with this method, which can be eliminated little bit by coagulating of silver chloride precipitate using nitrobenzene [5]. Fajans method [4-5] utilizes fluoresceinand dichlorofluorescein as adsorption indicator, but adsorption of indicator on precipitate depends on the experimental conditions. In turbidimetric titration [6-7] a chloride solution is titrated against silver nitrate and turbidity of silver chloridesuspension is measured for measurement of the chloride concentration. But the variation in particle dimension of silver chloride during the course of the turbidimetric titration does not produce correct end point in the titration curve.
Furthermore, chloride concentration is also determined by direct titration against $\mathrm{Hg}\left(\mathrm{NO}_{3}\right)_{2}$ using diphenyl carbazone indicator [8]. The mixture of diphenyl carbazone with bromothymol blue gives the better end point of the titration [9]. But without precise adjustment of the $\mathrm{pH}$ in between 3.2-3.3, the detection of the exact end point is a difficult task in this titration. All above mentioned titrimetric methods of chloride determination are allied with some kind of difficulty. However, titrimetry is the most common, convenient and favorite tool in all laboratories due to its inherent reproducibility, accuracy and low costing absolute method of analysis. In the earlier study [10], we utilized $\mathrm{Hg}\left(\mathrm{NO}_{3}\right)_{2}$ reagent and $\mathrm{Hg}(\mathrm{SCN})_{2}-\mathrm{Fe}\left(\mathrm{NO}_{3}\right)_{3}$ indicator system for titrimetric determination of ranitidine hydrochloride, via determining the chloride content of its hydrochloride salt.

Literature survey does not provide a mercurimetric assay of the chloride concentration in the water of green coconut by using a $\mathrm{Hg}(\mathrm{SCN})_{2}-\mathrm{Fe}\left(\mathrm{NO}_{3}\right)_{3}$ indicator system. So the original titrimetric approach for simple and rapid quantitation of chloride is proposed here. In the present study initially an indicator solution was prepared by titrating of $\mathrm{Hg}\left(\mathrm{NO}_{3}\right)_{2}$ against KSCN up to the faint red color (first end point), using $\mathrm{Fe}\left(\mathrm{NO}_{3}\right)_{3}$. Then a known amount of $\mathrm{Hg}\left(\mathrm{NO}_{3}\right)_{2}$ was added to indicator solution and further titrated against the water of green coconut till the original red color reappeared (second end point). The concentration of chloride present in the volume (of coconut water) utilized in between these two end points was found to be reacting in the 2:1 stoichiometric ratio with the $\mathrm{Hg}\left(\mathrm{NO}_{3}\right)_{2}$ taken for the second step of the titration.

\section{MATERIALS AND METHODS}

Materials

Analytical grade chemicals and distilled water were used throughout the experimentation. A standard $0.05 \mathrm{M} \mathrm{NaCl}$ and $\mathrm{KSCN}$ solutions 
were prepared. A $0.05 \mathrm{M} \mathrm{Hg}\left(\mathrm{NO}_{3}\right)_{2}$ solution was prepared in $0.5 \mathrm{M}$ nitric acid $\left(\mathrm{HNO}_{3}\right)$. A $0.2 \mathrm{M} \mathrm{Fe}\left(\mathrm{NO}_{3}\right)_{3}$ solution was prepared in $2.0 \mathrm{M}$ perchloric acid $\left(\mathrm{HClO}_{4}\right)$. The molarity of $\mathrm{Hg}\left(\mathrm{NO}_{3}\right)_{2}$ was adjusted exactly equal to $0.05 \mathrm{M}$ by standardization against standard $0.05 \mathrm{M}$ KSCN. A standard $0.05 \mathrm{M}$ disodium salt of ethylenediaminetetra acetic acid ( $\mathrm{Na}_{2}$-EDTA) and ammonia-ammonium chloride buffer (of $\mathrm{pH}=10$ ) were also prepared. Green coconuts of different maturity (1.5 to $6.0 \mathrm{mo}$ ) were obtained from the single coconut tree and subjected to analysis.

\section{Methods}

Step-I: Standardization of $\mathrm{Hg}\left(\mathrm{NO}_{3}\right)_{2}$ and preparation of indicator solution

Exactly $5.0 \mathrm{ml}$ of $0.05 \mathrm{M} \mathrm{Hg}\left(\mathrm{NO}_{3}\right)_{2}$ was transferred into a $250 \mathrm{ml}$ titration flask containing $10.0 \mathrm{ml}$ of $0.2 \mathrm{M} \mathrm{Fe}\left(\mathrm{NO}_{3}\right)_{3}$ in $2.0 \mathrm{M} \mathrm{HClO}$. This solution was titrated against standard $0.05 \mathrm{M}$ KSCN solution till a faint red color was developed. This termed here a first end point of the titration. The burette reading/volume of $\operatorname{KSCN}\left(\mathrm{V}_{2}\right)$ was recorded. The exact molarity $\left(\mathrm{M}_{\mathrm{S}}\right)$ of $\mathrm{Hg}\left(\mathrm{NO}_{3}\right)_{2}$ was determined by using following Eq. (1):

$$
M_{S}=\frac{\left(M_{2} \times V_{2}\right)}{\left(V_{1} \times N\right)} \ldots \text { Eq. (1) }
$$

In Eq.(1), $\mathrm{M}_{2}$ is the molarity of $\mathrm{KSCN}, \mathrm{V}_{1}$ is the volume of $\mathrm{Hg}\left(\mathrm{NO}_{3}\right)_{2}$ taken for the titration, $\mathrm{N}(=2)$ is the number of moles of $\mathrm{KSCN}$ reacting with one mole of $\mathrm{Hg}\left(\mathrm{NO}_{3}\right)_{2}$.

The solution obtained in this step of titration was used as an indicator for titration of $\mathrm{Hg}\left(\mathrm{NO}_{3}\right)_{2}$ against chloride solution in the second step. This indicator solution consists of small amount of red colored monothiocyanatoiron (III) nitrate, $[\mathrm{Fe}(\mathrm{SCN})]\left(\mathrm{NO}_{3}\right)_{2}$, an excess of $\mathrm{Hg}(\mathrm{SCN})_{2}$ and $\mathrm{Fe}\left(\mathrm{NO}_{3}\right)_{3}$.

\section{Step-II: Determination of chloride in coconut water}

After preparation of indicator solution by step-I, exactly $5.0 \mathrm{ml}$ of $0.05 \mathrm{MHg}\left(\mathrm{NO}_{3}\right)_{2}$ solution was added to indicator solution (it disappear red color) and titrated against coconut water till original red color reappeared. This termed here a second end point of the titration. The burette reading/volume $\left(\mathrm{V}_{\mathrm{c}}\right)$ of the coconut water was recorded. The molarity $\left(\mathrm{M}_{3}\right)$ of chloride in the coconut water was calculated using following Eq. (2).

$$
\mathrm{M}_{3}=\frac{\left(\mathrm{M}_{\mathrm{S}} \times \mathrm{V}_{\mathrm{S}} \times \mathrm{N}\right)}{\mathrm{V}_{\mathrm{C}}} \text {... Eq. (2) }
$$

In Eq. (2), $\mathrm{V}_{\mathrm{s}}$ is the volume of $\mathrm{Hg}\left(\mathrm{NO}_{3}\right)_{2}$ taken for titration in the second step and $\mathrm{N}(=2)$ is the number of moles of chloride reacting with one mole of $\mathrm{Hg}\left(\mathrm{NO}_{3}\right)_{2}$. The strength of chloride in $\mathrm{g} / \mathrm{l}$ (viz. $\mathrm{mg} / \mathrm{ml}$ ) was calculated by multiplying $\mathrm{M}_{3}$ with the atomic weight of chlorine $(\mathrm{AW}=35.5)$. The total amount of chloride $(\mathrm{C} \mathrm{cl})$ in $\mathrm{ppm}$ (mg/l) was calculated by using following Eq. (3):

$$
\mathrm{C}_{\mathrm{Cl}}=\mathrm{M}_{3} \times \mathrm{AW} \times 1000 \ldots \text { Eq. (3) }
$$

\section{Assay of chloride by standard addition method}

In the flask of an indicator solution, exactly $5.0 \mathrm{ml}$ of standard $0.05 \mathrm{MHg}\left(\mathrm{NO}_{3}\right)_{2}$ was transferred. Then a known amount of $(4.0 \mathrm{ml}$ or $6.0 \mathrm{ml}$ of $0.05 \mathrm{M} \mathrm{NaCl}$ ) was added as a standard chloride and the solution was further titrated against coconut water till faint red color end point. The burette reading/volume $\left(\mathrm{V}_{\mathrm{c}}\right)$ of coconut water was used for calculation of $\mathrm{M}_{3}$ as follow:

$$
\mathrm{M}_{3}=\frac{\left[\left(\mathrm{M}_{\mathrm{S}} \times \mathrm{V}_{\mathrm{S}} \times \mathrm{N}\right)-\left(\mathrm{M}_{\mathrm{NaCl}} \times \mathrm{V}_{\mathrm{NaCl}}\right)\right]}{\mathrm{V}_{\mathrm{C}}} \ldots \text { Eq. (4) }
$$

In Eq. (4), $\mathrm{M}_{\mathrm{NaCl}}$ and $\mathrm{V}_{\mathrm{NaCl}}$ respectively are the molarity and volume of the $0.05 \mathrm{M} \mathrm{NaCl}$. Then, the strength and the amount of chloride in the coconut water were calculated as explained above.

\section{RESULTS AND DISCUSSION}

Argentomety (using silver salts) and mercurimetry (using mercury salts) are only two suitable methods for quantitative determination of chloride in the different samples. The argentometric method was found to be applied for assay of many pharmaceutical substances through determining the chloride content in their hydrochloride salts [11-12]. The determination of chloride by mercurimetric titration is one of the well-known examples of complexometric titration [8]. Similar to the previous study [10], the essence of the present study is also based on the complexation of mercury (II), $\mathrm{Hg}(\mathrm{II})$ by chloride and thiocyanate ligands. In presence of known amount of thiocyanate ions, the titration reaction of chloride with $\mathrm{Hg}(\mathrm{II})$ was carried out in the 1:1 stoichiometric ratio, by making the reaction competitive for chloride and thiocyanate ions towards $\mathrm{Hg}(\mathrm{II})$ ion.

The value formation or stability constant $(\log K)$ of the complexes determine their stability [13-14]. The four log K values reported [1314] for the chloride complexes of $\mathrm{Hg}(\mathrm{II})$ does not differ widely. This designates simultaneously formation of $[\mathrm{Hg}(\mathrm{Cl})]^{+1}, \quad\left[\mathrm{Hg}(\mathrm{Cl})_{2}\right]$, $\left[\mathrm{Hg}(\mathrm{Cl})_{3}\right]^{-1}$ and $\left[\mathrm{Hg}(\mathrm{Cl})_{4}\right]^{-2}$ complexes, when reaction of chloride is carried out with $\mathrm{Hg}(\mathrm{II})$. For this reason, the correct reaction stoichiometry becomes indistinguishable in the direct titration of chloride against $\mathrm{Hg}(\mathrm{II})$.

The $\log K_{2}$ and $\log K_{4}$ values of thiocyanate complexes [13-14] designates the formation of $\left[\mathrm{Hg}(\mathrm{SCN})_{2}\right]$ and $\left[\mathrm{Hg}(\mathrm{SCN})_{4}\right]^{-2}$ complexes. The extensive difference in the $\log \mathrm{K}_{2}$ and $\log \mathrm{K}_{4}$ of the thiocyanate complexes, makes it possible to titrate $\mathrm{Hg}$ (II) against KSCN up to the reaction product $\mathrm{Hg}(\mathrm{SCN})_{2}$, using ferric ions indicator [5].

Both chloride and thiocyanate ions form adequately stable complexes with $\mathrm{Hg}(\mathrm{II})$. But the reactivity of chloride towards the $\mathrm{Hg}$ (II) ion is quite more; since it displaces the thiocyanate ions from $\mathrm{Hg}(\mathrm{SCN})_{2}$. This fact was used for spectrophotometric determination of chloride [15]. The same theme is also utilized here for detection of the end point in the titration of $\mathrm{Hg}(\mathrm{II})$ against chloride solution using $\mathrm{Hg}(\mathrm{SCN})_{2}$ indicator.

\section{Composition of the indicator system}

The step-I of the procedure describes the preparation of indicator solution. It was obtained by titrating $\mathrm{Hg}\left(\mathrm{NO}_{3}\right)_{2}$ against $\mathrm{KSCN}$ in the $1: 2$ stoichiometry [5] using $\mathrm{Fe}\left(\mathrm{NO}_{3}\right)_{3}$.

$$
\mathrm{Hg}\left(\mathrm{NO}_{3}\right)_{2}+2 \mathrm{KSCN} \rightarrow \mathrm{Hg}(\mathrm{SCN})_{2}+2 \mathrm{KNO}_{3}
$$

After equivalence point of the titration, a trace amount of KSCN reacts with $\mathrm{Fe}\left(\mathrm{NO}_{3}\right)_{3}$ gives the red colored $\left[\mathrm{Fe}(\mathrm{SCN})\left(\mathrm{NO}_{3}\right)_{2}\right]$ in the solution at the end point.

$$
\mathrm{KSCN}+\mathrm{Fe}\left(\mathrm{NO}_{3}\right)_{3} \rightarrow\left[\mathrm{Fe}(\mathrm{SCN})\left(\mathrm{NO}_{3}\right)_{2}\right]+\mathrm{KNO}_{3}
$$

Therefore, the indicator solution consists of a small amount of $\left[\mathrm{Fe}(\mathrm{SCN})\left(\mathrm{NO}_{3}\right)_{2}\right]$, an excess of $\left[\mathrm{Hg}(\mathrm{SCN})_{2}\right]$ and $\mathrm{Fe}\left(\mathrm{NO}_{3}\right)_{3}$. The use of $\mathrm{HClO}_{4}$ and $\mathrm{HNO}_{3}$ in the reagents gives acidic reaction medium ( $\mathrm{pH} \sim 0.80$ to 0.85 ) to which all reaction products are soluble and the solution was found to be homogenous.

\section{Chemistry of the titration reaction}

When a known amount of $\mathrm{Hg}\left(\mathrm{NO}_{3}\right)_{2}$ (viz. $5.0 \mathrm{ml}$ of $0.05 \mathrm{M}$ ) was added to the indicator solution, it reacts with $\mathrm{Hg}(\mathrm{SCN})_{2}$ and results in the formation of $\left[\mathrm{Hg}(\mathrm{SCN})\left(\mathrm{NO}_{3}\right)\right]$ as below:

$$
\mathrm{Hg}\left(\mathrm{NO}_{3}\right)_{2}+\mathrm{Hg}(\mathrm{SCN})_{2} \rightarrow 2\left[\mathrm{Hg}(\mathrm{SCN})\left(\mathrm{NO}_{3}\right)\right]
$$

The addition of $\mathrm{Hg}\left(\mathrm{NO}_{3}\right)_{2}$ also vanishes the red color of the indicator solution, because of the conversion of the $\left[\mathrm{Fe}(\mathrm{SCN})\left(\mathrm{NO}_{3}\right)_{2}\right]$ into $\mathrm{Hg}(\mathrm{SCN})_{2}$ as per the following reaction:

$$
\mathrm{Hg}\left(\mathrm{NO}_{3}\right)_{2+}\left[\mathrm{Fe}(\mathrm{SCN})\left(\mathrm{NO}_{3}\right)_{2}\right] \rightarrow \mathrm{Hg}(\mathrm{SCN})_{2+} \mathrm{Fe}\left(\mathrm{NO}_{3}\right)_{3}
$$

Even though the exactly same amount of $\mathrm{Hg}\left(\mathrm{NO}_{3}\right)_{2}$ was used in the both steps of the titration, then also a small amount of $\mathrm{Hg}(\mathrm{SCN})_{2}$ always generated in the indicator solution. The concentration of the generated $\mathrm{Hg}(\mathrm{SCN})_{2}$ presides over the amount of $\left[\mathrm{Fe}(\mathrm{SCN})\left(\mathrm{NO}_{3}\right)_{2}\right]$ formed in the first step of the titration. When lower amount $(1.0,2.0$, 3.0 or $4.0 \mathrm{ml})$ of $\mathrm{Hg}\left(\mathrm{NO}_{3}\right)_{2}$ was employed in the second step of the titration, then more amount of $\mathrm{Hg}(\mathrm{SCN})_{2}$ present in the indicator solution. It was observed that the additional concentration of $\mathrm{Hg}(\mathrm{SCN})_{2}$ in the indicator solution helps for detection of the sharp end point of the titration. When greater amount (more than $5.0 \mathrm{ml}$ ) of $\mathrm{Hg}\left(\mathrm{NO}_{3}\right)_{2}$ was used in the second step of the titration, then the formation of $\mathrm{Hg}(\mathrm{SCN})_{2}$ is not possible. At this condition, free $\mathrm{Hg}(\mathrm{II})$ 
ions (not linked to thiocyanate) are present in the indicator solution, those greatly affects the end point of the titration.

Thus, $\mathrm{Hg}(\mathrm{SCN})_{2}$ and $\left[\mathrm{Hg}(\mathrm{SCN})\left(\mathrm{NO}_{3}\right)\right]$ are the main reacting species generated in the solution, when exactly same amounts of $\mathrm{Hg}\left(\mathrm{NO}_{3}\right)_{2}$ were employed in both the steps of titration. When this solution was titrated against coconut water (in step-II) then the chloride ions reacts with the $\left[\mathrm{Hg}(\mathrm{SCN})\left(\mathrm{NO}_{3}\right)\right]$ by replacing the nitrate ions as shown below:

$$
\left[\mathrm{Hg}(\mathrm{SCN})\left(\mathrm{NO}_{3}\right)\right]+\mathrm{NaCl} \rightarrow[\mathrm{Hg}(\mathrm{SCN})(\mathrm{Cl})]+\mathrm{NaNO}_{3}
$$

The reaction is represented by using $\mathrm{NaCl}$.

As long as the reaction of chloride ions with $\left[\mathrm{Hg}(\mathrm{SCN})\left(\mathrm{NO}_{3}\right)\right]$ cannot be completed in the 1:1 stoichiometric ratio, the initially linked thiocyanate ions [to $\mathrm{Hg}(\mathrm{II})]$ does not allow for chloride ions to increase the coordination number of $\mathrm{Hg}(\mathrm{II})$ greater than two. Thus the reaction becomes competitive for chloride and thiocyanate ions for $\mathrm{Hg}(\mathrm{II})$ ion. After completion of this reaction in the $1: 1$ stoichiometric ratio, the extra chloride ions (of coconut water) displaces the thiocyanate ions from the $\mathrm{Hg}(\mathrm{SCN})_{2}$ and regenerates the red colored $\left[\mathrm{Fe}(\mathrm{SCN})\left(\mathrm{NO}_{3}\right)_{2}\right]$ at the end point of the second titration. This action of the indicator in presence of $\mathrm{Fe}\left(\mathrm{NO}_{3}\right)_{3}$ is represented by using $\mathrm{NaCl}$ as shown below:

$\mathrm{Hg}(\mathrm{SCN})_{2+} \mathrm{NaCl}+\mathrm{Fe}\left(\mathrm{NO}_{3}\right)_{3} \rightarrow[\mathrm{Hg}(\mathrm{SCN})(\mathrm{Cl})]+\left[\mathrm{Fe}(\mathrm{SCN})\left(\mathrm{NO}_{3}\right)_{2}\right]+\mathrm{NaNO}_{3}$

The identical red color intensity designates the equal concentration of $\left[\mathrm{Fe}(\mathrm{SCN})\left(\mathrm{NO}_{3}\right)_{2}\right]$ at both the end points of the titrations. Therefore, the concentration of chloride in the volume (of coconut water) utilized between two end points was found reacting in the 1:1 stoichiometric ratio with $\left[\mathrm{Hg}(\mathrm{SCN})\left(\mathrm{NO}_{3}\right)\right]$ or in the $2: 1$ stoichiometric ratio with $\mathrm{Hg}\left(\mathrm{NO}_{3}\right)_{2}$ taken in the second step of the titration.

\section{Effect of the concentration of $\mathrm{Hg}\left(\mathrm{NO}_{3}\right)_{2}$ on the reaction stoichiometry}

The proposed procedure was first implemented for assay of chloride in the range 177.5 to 1775 ppmusing standard $0.005 \mathrm{M}$ to $0.05 \mathrm{M}$ $\mathrm{NaCl}$ solutions. In this study, the number $(\mathrm{N})$ of moles of chloride reacting with one mole of $\mathrm{Hg}\left(\mathrm{NO}_{3}\right)_{2}$ viz. reaction stoichiometry was calculated by using following Eq. (5):

$$
\mathrm{N}=\frac{\left(\mathrm{M}_{3} \times \mathrm{V}_{3}\right)}{\left(\mathrm{M}_{\mathrm{S}} \times \mathrm{V}_{\mathrm{S}}\right)}
$$

In Eq. (5), $\mathrm{M}_{3}$ and $\mathrm{V}_{3}$ are molarity and burette reading of $\mathrm{NaCl}$ solution. It was observed that the reaction stoichiometry was found to be 2:1 [chloride: $\mathrm{Hg}\left(\mathrm{NO}_{3}\right)_{2}$ ] with that amount of $\mathrm{Hg}\left(\mathrm{NO}_{3}\right)_{2}$ taken in the second step of the titration.

The value of $\mathrm{N}$ found to be correct only when the concentration of the $\mathrm{Hg}\left(\mathrm{NO}_{3}\right)_{2}$ employed in the second titration was smaller or equal to that was taken for preparation of indicator solution. At this experimental condition $\left[\mathrm{Hg}(\mathrm{SCN})\left(\mathrm{NO}_{3}\right)\right]$ and $\mathrm{Hg}(\mathrm{SCN})_{2}$ were the reacting species in the titration flask.

The value of $\mathrm{N}$ was found to be get increased when more amount (greater than $5.0 \mathrm{ml}$ ) of $\mathrm{Hg}\left(\mathrm{NO}_{3}\right)_{2}$ employed in the second step of the titration. At this condition $\left[\mathrm{Hg}(\mathrm{SCN})\left(\mathrm{NO}_{3}\right)\right]$ and free $\mathrm{Hg}(\mathrm{II})$ ions (not lined with thiocyanate) were the reacting species in the reaction mixture. These free $\mathrm{Hg}(\mathrm{II})$ ions are reacting with chloride by giving chloro-complexes of coordination number greater than two. At this situation, after complexation of $\mathrm{Hg}(\mathrm{II})$ ions, the development of the red color at the end point of the titration is associated with the following reaction:

$$
[\mathrm{Hg}(\mathrm{SCN})(\mathrm{Cl})]+\mathrm{NaCl}+\mathrm{Fe}\left(\mathrm{NO}_{3}\right)_{3} \rightarrow \mathrm{Hg}(\mathrm{Cl})_{2+}\left[\mathrm{Fe}(\mathrm{SCN})\left(\mathrm{NO}_{3}\right)_{2}\right]+\mathrm{NaNO}_{3}
$$

\section{The concentration range for the assay of chloride}

The proposed procedure was tested and found to be suitable for determination of chloride in the range 177.5 to $1775 \mathrm{ppm}$. The procedure showed little bit poor performance with analyte solutions having chloride concentration less than $177.5 \mathrm{ppm}$. This is because of the dilute solution of chloride increases the volume of titration mixture in which the end point becomes indistinguishable. But the procedure was also found excellent for determination chloride concentration greater than $1775 \mathrm{ppm}$. The chloride up to $4227 \mathrm{ppmin}$ the coconut water was determined by the proposed procedure.

\section{Effect of the sulfate and phosphate on the assay of chloride}

The water of the green coconut consists of a mixture of many organic compounds as well as the inorganic cations and anions [2-3]. The chloride, sulfate, and phosphate are the main inorganic anions found in the coconut water [16]. The silver salts of sulfate and phosphate are slightly insoluble in neutral solution; therefore, these anions are showing interference in the determination of chloride by Mohr's method [14]. The phosphate ions of the coconut water develop yellowish-red coloration with the ferric ions in the neural or basic solution. The interfering role of the sulfate and phosphate was studied by determining their effect on the reaction stoichiometry.

In this study, the titration reaction was carried against standard $0.05 \mathrm{M} \mathrm{NaCl}$ solution by the recommended procedure. The burette reading/volume of $0.05 \mathrm{M} \mathrm{NaCl}$ was used for calculation of the $\mathrm{N}$ value of the reaction by using Eq. (5). Then, a known volume of 4000 ppm of phosphate (prepared using $\mathrm{Na}_{2} \mathrm{HPO}_{4}$ ) or sulfate (prepared using $\mathrm{Na}_{2} \mathrm{SO}_{4}$ ) solution was mixed with the same volume of $0.05 \mathrm{M}$ $\mathrm{NaCl}$ solution. The burette reading of the resulting $0.025 \mathrm{M} \mathrm{NaCl}$ solution containing $2000 \mathrm{ppm}$ of phosphate or sulfate was obtained and $\mathrm{N}$ value was determined. In both the determinations, constant $\mathrm{N}$ value was obtained. This designates that the concentration of phosphate and sulfate up to $2000 \mathrm{ppm}$ can be tolerated by this method in determination of chloride. The acidic $(\mathrm{pH} \sim 0.85)$ condition of the reaction, does not allow phosphate and sulfate to form compounds with $\mathrm{Hg}(\mathrm{II})$. The additional study also showed that glucose and fructose up to $2000 \mathrm{ppm}$ did not show their interference in chloride determination by this procedure.

\section{Accuracy and precision in determination of chloride}

The five replicate determination of chloride were carried out by using standard $0.005 \mathrm{M}, 0.01 \mathrm{M}, 0.025 \mathrm{M}, 0.04 \mathrm{M}$ and $0.05 \mathrm{M} \mathrm{NaCl}$ solutions. The accuracy and precision of the measurement are calculated in the form of relative error and average deviation respectively. The results presented in table- 1 indicate the proposed

\begin{tabular}{|c|c|c|c|c|c|c|c|}
\hline $\begin{array}{l}\text { Molarity } \\
\text { of the NaCl } \\
\text { solution } \\
\text { analyzed (M) }\end{array}$ & $\begin{array}{l}\text { Expected } \\
\text { Concentration } \\
\text { of the chloride } \\
\text { (ppm) }\end{array}$ & $\begin{array}{l}\text { Molarity of } \\
\text { the NaCl } \\
\text { found a } \\
\text { (M) }\end{array}$ & $\begin{array}{l}\text { Concentration } \\
\text { of chloride } \\
\text { in found a } \\
\text { (ppm) }\end{array}$ & $\begin{array}{l}\text { Absolute } \\
\text { error in the } \\
\text { measurement a } \\
\text { (ppm) }\end{array}$ & $\begin{array}{l}\text { Relative error } \\
\text { in the } \\
\text { measurement } \\
(\%)\end{array}$ & $\begin{array}{l}\text { Deviation } \\
\text { in the } \\
\text { measurement }\end{array}$ & $\begin{array}{l}\text { Average } \\
\text { deviation } \\
\text { in the } \\
\text { measurement }^{\mathrm{a}}\end{array}$ \\
\hline 0.005 & 177.5 & 0.00499 & 177.18 & -0.316 & -0.178 & -0.01 & -0.002 \\
\hline 0.010 & 355.0 & 0.01004 & 356.48 & 1.477 & 0.416 & 0.01 & 0.002 \\
\hline 0.025 & 887.5 & 0.02520 & 894.71 & 7.208 & 0.812 & 0.00 & 0.000 \\
\hline 0.040 & 1420.0 & 0.04000 & 1420.11 & 0.114 & 0.008 & 0.01 & 0.002 \\
\hline 0.050 & 1775.0 & 0.05010 & 1778.66 & 3.657 & 0.206 & -0.01 & -0.002 \\
\hline
\end{tabular}
procedure is accurate and precise.

Table 1: Results obtained in determination of accuracy and precision in determination of chloride by the proposed procedure

aThe average of the five determinations ( $\mathrm{n}=5)$ 


\section{Application of the procedure in the assay of chloride}

Coconut water is enriched in minerals such as potassium, sodium, calcium, magnesium etc. in the form of their sulfate, phosphate and chloride salts. The taste of the coconut water is largely governed by the concentration of these minerals and their co-ions [2-3]. Therefore, the proposed procedure was applied for quantitative determination of chloride in the coconut water.

The results of this analysis are represented in table 2 . The data shown in table 2 illustrates that the concentration of chloride in the coconut water was get decreased with the maturity of coconut fruits. At the stage of complete maturity (5.5 to $6.0 \mathrm{mo}$ ) the level of chloride concentration was found to be a little bit increased. This is because of the utilization of water in the production of the coconut meat. The decrease in the amount of water in the coconut fruit increases the level of chloride. Consequently, the water of immature coconuts (of the ages 2 to $3 \mathrm{mo}$ ) is highly enriched in mineral, so it is a good refreshing drink.

\section{Determination of cationic mineral value of the coconut water}

The cationic mineral value (CMV) of the coconut water is determined in terms of a number of milligrams of the disodium salt of ethylenediaminetetra-acetic acid $\left(\mathrm{Na}_{2}\right.$-EDTA. $2 \mathrm{H}_{2} 0 ; \mathrm{M}$. W. $\left.=372.24\right)$ required for complete complexation/chelation of the cations present in the one liter of coconut water and it is expressed here in ppm. Ethylene-diaminetetra-acetic acid is the most versatile chelating reagent used for determination of divalent and trivalent metal ions in basic and acidic medium respectively [4]. The trivalent metal ions are also reacting vigorously with EDTA in basic medium. Therefore, the CMV was determined by using $\mathrm{Na}_{2}$-EDTA at basic $\mathrm{pH}$. With the Eriochrome black $\mathrm{T}$ indicator, a $10 \mathrm{ml}$ aliquot of the coconut water buffered at $\mathrm{pH} 10$ (using $5.0 \mathrm{ml}$ of ammonia-ammonium chloride buffer [4]) was titrated against standard $0.05 \mathrm{M} \mathrm{Na}$-EDTA till the development of the permanent blue color. The burette reading/volume of $\mathrm{Na}_{2}$-EDTA $\left(\mathrm{V}_{\text {EDTA }}\right)$ was utilized for determination of the CMV of the $1000 \mathrm{ml}$ of coconut water in ppm as follows:

$$
\mathrm{CMV}=18.612 \times \mathrm{V}_{\mathrm{EDTA}} \times 100 \ldots(6)
$$

Coconut water consists of various cations such as potassium, sodium, calcium, magnesium etc [2-3]. The measurement of the CMV of the coconut water is related to the determination of the concentration of those positively charged mineral ions which form the stable chelate with EDTA. The cations like sodium, potassium etc, which do not form the stable chelate with EDTA and therefore their concentration is not involved in the CMV. The results of the determination of the CMV are represented in table 2. This data shown (table 2) demonstrates that the CMV of the coconut water was found to be get decreased with their maturity. During the maturity the minerals are utilized for production of coconut meat consequently, the CMV was found to be decreasing with the maturity of the coconut fruits.

\section{Assay of the chloride by standard addition method}

The effect of the other organic matter present in the coconut water, as well as accuracy of the proposed procedure, was further ascertained by determining the chloride concentration using standard addition method. The same samples of the coconut water were analyzed for determination of chloride concentration by standard addition method as described in the procedure. On comparing the results represented in table 2 and table 3 , it is clear that neither the end-point of the titration nor the molarity of chloride was affected by the common sample matrix present in coconut water.

Table 2: Results obtained in quantitative determination of chloride in the water of green coconuts and the correlation of the chloride concentration with the cationic mineral value determined by the complexometric titration

\begin{tabular}{|c|c|c|c|c|c|}
\hline $\begin{array}{l}\text { Maturity of } \\
\text { the coconut } \\
\text { fruit } \\
\text { (months) }^{b}\end{array}$ & $\begin{array}{l}\text { Molarity of the } \\
\text { chloride found in } \\
\text { coconut water } \\
\text { (M) }\end{array}$ & $\begin{array}{l}\text { Total chloride } \\
\text { found in the } \\
\text { coconut water } \\
\text { (ppm) }\end{array}$ & $\begin{array}{l}\text { Average chloride } \\
\text { concentration found in } \\
\text { the coconut water } \\
(\mathrm{ppm})\end{array}$ & $\begin{array}{l}\text { Cationic mineral } \\
\text { value of the } \\
\text { coconut water } \\
\text { (ppm) }\end{array}$ & $\begin{array}{l}\text { Average of the cationic } \\
\text { mineral value of the } \\
\text { coconut water } \\
(\mathrm{ppm})\end{array}$ \\
\hline \multirow[t]{3}{*}{1.5} & 0.1188 & 4218.10 & & 13103 & \\
\hline & 0.1194 & 4237.46 & & 13066 & \\
\hline & 0.1190 & 4222.88 & 4226.15 & 13066 & 13078 \\
\hline \multirow[t]{3}{*}{2.0} & 0.1090 & 3872.98 & & 11800 & \\
\hline & 0.1087 & 3858.76 & & 11763 & \\
\hline & 0.1085 & 3850.39 & 3860.71 & 11763 & 11775 \\
\hline \multirow[t]{3}{*}{2.5} & 0.0917 & 3256.88 & & 10125 & \\
\hline & 0.0932 & 3307.45 & & 10088 & \\
\hline & 0.0926 & 3287.04 & 3283.79 & 10088 & 10100 \\
\hline \multirow[t]{3}{*}{3.0} & 0.0907 & 3219.77 & & 9157 & \\
\hline & 0.0852 & 3025.57 & & 9120 & \\
\hline & 0.0856 & 3039.38 & 3094.91 & 9120 & 9132 \\
\hline \multirow[t]{3}{*}{3.5} & 0.0813 & 2886.18 & & 8859 & \\
\hline & 0.0815 & 2894.02 & & 8822 & \\
\hline & 0.0815 & 2894.02 & 2898.61 & 8822 & 8834 \\
\hline \multirow[t]{3}{*}{4.0} & 0.0752 & 2669.17 & & 8152 & \\
\hline & 0.0754 & 2675.88 & & 8078 & \\
\hline & 0.0753 & 2673.19 & 2672.75 & 8078 & 8102 \\
\hline \multirow[t]{3}{*}{4.5} & 0.0662 & 2350.99 & & 7296 & \\
\hline & 0.0664 & 2356.19 & & 7333 & \\
\hline & 0.0663 & 2354.11 & 2353.77 & 7333 & 7321 \\
\hline \multirow[t]{3}{*}{5.0} & 0.0543 & 1929.35 & & 6477 & \\
\hline & 0.0543 & 1929.35 & & 6440 & \\
\hline & 0.0542 & 1925.16 & 1927.95 & 6440 & 6452 \\
\hline \multirow[t]{3}{*}{5.5} & 0.0606 & 2151.52 & & 5249 & \\
\hline & 0.0607 & 2155.87 & & 5286 & \\
\hline & 0.0608 & 2159.37 & 2155.58 & 5286 & 5273 \\
\hline \multirow[t]{3}{*}{6.0} & 0.0602 & 2138.55 & & 4504 & \\
\hline & 0.0602 & 2138.55 & & 4504 & \\
\hline & 0.0601 & 2133.41 & 2136.84 & 4467 & 4492 \\
\hline
\end{tabular}

aThe average values of the six determinations $(n=6),{ }^{b}$ The approximate maturity in months of the coconut fruits as told by the farmer 
Table 3: Results obtained for the quantitative determination of chloride in the water of green coconuts by using the standard addition method

\begin{tabular}{|c|c|c|c|c|c|}
\hline $\begin{array}{l}\text { Maturity of } \\
\text { the coconut } \\
\text { fruit } \\
\text { (mo) }{ }^{\mathrm{b}}\end{array}$ & $\begin{array}{l}\text { Volume of } 0.05 \mathrm{M} \\
\mathrm{Hg}\left(\mathrm{NO}_{3}\right)_{2} \text { taken } \\
\text { for the titration } \\
(\mathrm{ml})\end{array}$ & $\begin{array}{l}\text { Volume of } 0.05 \mathrm{M} \mathrm{NaCl} \\
\text { solution initially } \\
\text { added as standard } \\
\text { (ml) }\end{array}$ & $\begin{array}{l}\text { Burette Reading/volume } \\
\text { of the coconut water } \\
\text { required for the titration } \\
\text { (ml) }\end{array}$ & $\begin{array}{l}\text { Molarity of } \\
\text { chloride found in } \\
\text { the coconut water } \\
\text { (M) }\end{array}$ & $\begin{array}{l}\text { Total amount of } \\
\text { chloride found in } \\
\text { the coconut water } \\
\text { (ppm) }\end{array}$ \\
\hline \multirow[t]{2}{*}{1.5} & 5.0 & 4.0 & 2.52 & 0.1189 & 4220.7 \\
\hline & 5.0 & 6.0 & 1.68 & 0.1188 & 4218.1 \\
\hline \multirow[t]{2}{*}{2.0} & 5.0 & 4.0 & 2.76 & 0.1087 & 3858.7 \\
\hline & 5.0 & 6.0 & 1.84 & 0.1088 & 3862.3 \\
\hline \multirow[t]{2}{*}{2.5} & 5.0 & 4.0 & 3.23 & 0.0929 & 3297.3 \\
\hline & 5.0 & 6.0 & 2.18 & 0.0916 & 3252.0 \\
\hline \multirow[t]{2}{*}{3.0} & 5.0 & 4.0 & 3.42 & 0.0878 & 3117.1 \\
\hline & 5.0 & 6.0 & 2.25 & 0.0890 & 3160.5 \\
\hline \multirow[t]{2}{*}{3.5} & 5.0 & 4.0 & 3.64 & 0.0825 & 2928.6 \\
\hline & 5.0 & 6.0 & 2.47 & 0.0811 & 2878.4 \\
\hline \multirow[t]{2}{*}{4.0} & 5.0 & 4.0 & 3.99 & 0.0752 & 2669.2 \\
\hline & 5.0 & 6.0 & 2.67 & 0.0750 & 2662.5 \\
\hline \multirow[t]{2}{*}{4.5} & 5.0 & 4.0 & 4.54 & 0.0660 & 2344.1 \\
\hline & 5.0 & 6.0 & 3.02 & 0.0663 & 2353.6 \\
\hline \multirow[t]{2}{*}{5.0} & 5.0 & 4.0 & 5.59 & 0.0537 & 1906.3 \\
\hline & 5.0 & 6.0 & 3.71 & 0.0540 & 1915.5 \\
\hline \multirow[t]{2}{*}{5.5} & 5.0 & 4.0 & 4.93 & 0.0608 & 2158.8 \\
\hline & 5.0 & 6.0 & 3.29 & 0.0609 & 2160.3 \\
\hline \multirow[t]{2}{*}{6.0} & 5.0 & 4.0 & 4.99 & 0.0601 & 2132.9 \\
\hline & 5.0 & 6.0 & 3.33 & 0.0600 & 2130.0 \\
\hline
\end{tabular}

aThe average values of the six determinations $(n=6),{ }^{\text {tT }}$ The approximate maturity in months of the coconut fruits as told by the farmer

\section{CONCLUSION}

In conclusion, the proposed procedure is quite simple, inexpensive and highly selective for determination of chloride in the water of coconuts containing sulfate, phosphates, glucose, fructose, other organic compounds and many inorganic minerals. This procedure is also excellent for determination of chloride in other acidic sample solutions without precise adjustment of the $\mathrm{pH}$ for detection of the end point. Owing to the homogenous reaction condition no titration errors those are commonly encountered by co-precipitation in the argentometric assay of chloride.

\section{ACKNOWLEDGEMENT}

The author is grateful to the Managing Committee of the Maratha Vidya Prasarak (MVP) Samaj, Nashik for providing the necessary infrastructure and instrumentations. This article is dedicated to late Dr. Daulatrao Sonuji Aher (01.11.1942 to 19.01.2016), the former President of the MVP Samaj Nashik and the former Health Minister of the Maharashtra State.

\section{CONFLICT OF INTERESTS}

Declared none

\section{REFERENCES}

1. Ewansiha CJ, Ebhoaye JE, Asia IO, Ekebafe LO, Ehigie C. Proximate and mineral composition of coconut (Cocos Nucifera) shell. Int J Pure Appl Sci Technol 2012;13:57-60.

2. Kuberski T, Roberts A, Linehan B, Bryden RN, Teburae M. Coconut water as rehydration fluid. N Z Med J 1979;90:98100.

3. Adams W, Bratt DE. Young coconut water for home rehydration in children with mild gastroenteritis. Trop Geogr Med 1992;44:149-53.

4. Jeffery GH, Bassett J, Mendham J, Denny RC. Vogel's textbook of quantitative analysis. 5th ed. England UK: Longmann Group Ltd; 1989. p. 690, 353, 350.

5. Furman NH. Editor. Standard Methods of Chemical Analysis. Vol. 1. The Elements. 6th ed. In Chap 14-Chlorine and Chap 29-
Mercury, Malabar-Florida, Robert E: Krieger Publishing Company; 1962. p. 332, 329, 662.

6. Meehan EJ, Chiu G. Principles of turbidimetric and nephelometric titrations. Anal Chem 1964;36:536-40.

7. Kolthoff IM, Yutzy H. The nephelometric determination of chloride. J Am Chem Soc 1933;55:1915-22.

8. Day RA Jr, Underwood AL. Quantitative Analysis. 6th ed. New Delhi: Prentice-Hall of India Private Ltd; 1993. p. 220.

9. Clarke FE. Determination of chloride in water improved colorimetric and titrimetric methods. Anal Chem 1950;22:553-5.

10. Labhade SR, Labhade KR, Harak PD, Gaikwad VB. Titrimetric assay of ranitidine hydrochloride using mercury (II) nitrate reagent and mercury (II) thiocyanate-iron (III) nitrate indicator system. Indo Am J Pharm Res 2016;6:2246-53.

11. Al Bratty M, Hashem H, Noureldeen A, Manoharan G, Towhari F. Conductometric determination of the antihistaminic diphenhydramine hydrochloride using silver nitrate as a titrant. Int J Pharm Pharm Sci 2015;7:72-6.

12. Ayad M, Abdellatef H, Hosny M, Sharaf Y. Conductometric titration method for determination of etilefrine hydrochloride, fenoterol hydrochloride and pipazenthate hydrochloride using silver nitrate. Innovare J Med Sci 2016;4:14-7.

13. Speight JG. Lange's Handbook of Chemistry. 16th ed. New York: McGraw-Hill; 2005. p. 1358-62.

14. Patnaik P. Dean's analytical chemistry. 2nd ed. New York: McGraw-Hill; 2004. p. 29.

15. Yoshinaga T, Ohta K. Spectrophotometric determination of chloride ion using mercury thiocyanate and iron alum. Anal Sci 1990;6:57-60.

16. Eduardo MR, Dosil P, de J, Rodrigo AAM, Claudimir L do L, Lúcio A. Determination of anions, cations, and sugars in coconut water by capillary electrophoresis. J Braz Chem Soc 2005;16:1134-9.

\section{How to cite this article}

- Shivaji Rangnath Labhade. Selective mercurimetric titration assay of chloride concentration in the water of green coconuts using novel indicator system. Int J Pharm Pharm Sci 2017; 9(3):268-272. 